\title{
REVEALING A JAVANESE IDENTITY OF PRAYER IN THE WEDHATAMA THROUGH SEMANTIC PROPOSITION
}

\author{
Tantri Refa Indhiarti', Sri Utami Budi', and Indah Winarni ${ }^{3}$ \\ Department of Language and Literature \\ Brawijaya University Indonesia \\ tantri.refa@gmail.com
}

\begin{abstract}
The Wedhatama, a Javanese literary work by the King Mangkunegara IV contains philosophical teachings which are quite influential in ethical life. This paper aims at discovering the hidden meaning of the teachings which reveal an esoteric knowledge of worshipping in terms of its semantic point of view. This meaning is known through analytic and synthetic propositions in Gambuh canto associated with 4 different types of worship. Thus, the qualitative paradigm is used in which the data were obtained through library research. In this study, the synthetic proposition shows the breadth of the poet's signifying esoteric intention that is about Javanese identity of prayer. It is revealed that the four types of worship -sembah raga, cipta, jiwa, and rasa-are said to coincide with what are usually referred to in Muslim Sufism as syariat.
\end{abstract}

Keywords: Gambuh canto, the Wedhatama, Javanese identity of prayer, semantic proposition

\begin{abstract}
Abstrak
Wedhatama, sebuah karya sastra Indonesia dari Kerajaan Mangkunegara IV yang berisi ajaran-ajaran filosofis yang sangat berpengaruh dalam tata cara kehidupan. Penelitian ini bertujuan untuk meneliti makna tersembunyi dari ajaran-ajaran tersebut dengan mengungkap pengetahuan rahasia dalam istilah-istilah sembahyang dari sudut pandang semantik. Pengungkapan makna ini diteliti melalui proposisi-proposisi analitis dan sintesis dalam nyanyian Gambuh yang terhubung dengan 4 jenis sembahyang. Oleh sebab itu, paradigma kualitatif digunakan dalam penelitian ini bahwa data diperoleh dari kajian pustaka. Dalam penelitian ini, pernyataan sintesis menunjukkan nafas puisi yang menandakan maksud rahasia adalah tentang identitas sembahyang orangorang Jawa. Ada 4 tipe sembahyang yaitu sembah raga, cipta, jiwa, dan rasa yang konon mengacu pada Sufisme Muslim sebagai syariat.
\end{abstract}

\section{Introduction}

As one of important authors in the Javanese environment, Mangkunegara IV was widely recognized as a prolific writer whose work expresses a positive attitude toward life and praises the mystical composition of Java. His famous poem is the Wedhatama containing the highest wisdom cast in a mould of poetic language (Robson, 1990). It is composed of four parts or canto; the first part is named pangkur, the second is sinom, the third is pucung and the fourth is gambuh. The last canto is the focus of this study as it describes the highest knowledge that is achieved through praxis and experiential by nature (Boogert, 2015). It is devoted to the concept of worship which consists of four kinds 
pertaining to the body, thought, soul, and essence similar to the concept in Islam (Robson, 1990, p.16). In accordance with this knowledge, Woodward (2011, p.77-79) states that the concept is essentially Islamic and is understood by the Javanese in this fashion as knowledge of mystical nature. In such a way, spiritual power derives from regular observance of prayer and force that overpowers all other kinds of power. Verse 14 of canto 1 claims this notion in Robson (1990):

Truly such a man/ Has been granted grace by God;/ He has returned to the realm of the Void/... What had the quality of power has itself been overpowered...

In Gambuh too, in accordance with Widodo's research (2015) the concept of Javanese Sufism, the mystical concept of the union between man and God (manunggaling kawula Gusti) is elaborated. Therefore, in order to attain a deep understanding of this union, a formula known as sembah catur or four kinds of homage is described as a way of gaining the grace of God. Furthermore, the efforts to discover the meanings implied in Gambuh also lead to the argument that the four kinds of homage may serve as a warning and moral education that have significant values for someone to draw closer to God (Sulistyo, 2015). These previous researches are delimited to the pragmatic analysis suggesting that the dominant implicatures in Gambuh are the four types of homage. Besides, they are focused on describing the theological value which is considered as a successful discourse of harmony among traditional Javanese principles and Islamic principles.

Although the aforementioned researches have been conducted to analyse the Wedhatama, numerous approaches of literary analysis, such as semantic proposition are possible to gain to prove the Javanese identity in worship. As can be seen in the Wedhatama, the poet is expressing a very Javanese nostalgia for that more Javanese style of prayer. The levels of interiority are more explicitly described in canto 4, Gambuh. The world touched on in Gambuh is merely about spiritual teaching as included in Islam in the sense of Javanese style of prayer (Headley, 2004). As far as the researchers have been able to establish, little research has been performed regarding Javanese conception of this esoteric knowledge through the analytic and synthetic propositions used. Therefore, this seeming convergence of knowledge at face value that in Gambuh canto this knowledge has Javanese meaning is taken in this study.

To know that identity of Javanese society, it is significant to look at how they are hooked up to the world concerning the propositions used. As proposition is commonly treated as the semantic contents of sentences, there is room for doubt about whether it is the right sort of entity for the job. This definition is dealing with what McGrath (2005) says that a sentence may seem to be true depending on whether the proposition or content is true in a world and it may be false if it is seen from another view of world. Specifically, according to Mundiri (2001) there are two kinds of propositions, namely analytic proposition whose predicate has meaning already contained in the subject. There are two ways to conceive the truth value of such proposition (Mundiri, 2001, p.9): 1) it is noticed by knowing the compatibility between mind and reality; for example, 'the Quran is given to the Prophet Muhammad.' Within the Muslim community the Quran is a sacred scripture given to the Prophet Muhammad and to all who followed his message and consists of God's eternal speech. In such a case, the proposition is appropriate to the reality occurring in the Muslim community. 2) It is noticed by knowing the inexistence of contradiction in the proposition. For example, 'he is an honest man who likes lying.' The subject word 'honest' is defined into 'an adjective of a person telling the truth, not lying.' The example is said to 
be false since there is a contradiction between the subject 'honest' and the predicate 'lying.' The proposition will be analytically true if there is no contradiction 'lying' that explains 'an honest man.'

Furthermore, synthetic proposition is the one where the predicate has meaning that is not necessary for the subject. For example, 'that girl is fat.' The meaning of the predicate is not a necessity for the subject 'that girl.' In this case, 'fat' is additional information obtained from the observation of physical appearance of 'that girl.' To conceive the truth value of the proposition is by observing the reality in the world.

Related to analytic and synthetic propositions proposed by Mundiri (2001), there is another similar notion on both propositions by Palmer (1981). Palmer (1981, p.111) assumes that a proposition can be distinguished into two, namely "the one necessary and depending upon logical operations, the other contingent and depending upon facts about the world". The first proposition is derived from the definition of a word and is called analytic proposition. There are ways to count the truth in analytic proposition: 1) the truth is obtained regarding the logical relation found in the proposition, such as by relating the subject and the definition of the subject, which in this case is functioned as the predicate of the proposition. Thus there is no additional knowledge which is found in the subject since the predicate states only the explanation needed by the subject. 2) According to Palmer (1981, p.111), sense relation is a way to know the truth of analytic proposition. Sense is an aspect of meaning which talks about the relationship within the linguistic elements, namely words (Palmer, 1981, p.30). In talking sense, it is not necessary to concern with the external world because sense is obtained by relating word to word.

Moreover, according to Palmer (1981, p.59) there are several ways through which the truth of analytic proposition is acknowledged: 1) synonymy is the relationship of sameness of meaning, such as 'brotherly' and 'fraternal.' 2) Hyponymy is the relationship of inclusion that the meaning of one word is included in the meaning of another. For example, 'tulip' and 'rose' are included in 'flower.'

On the contrary, the second proposition, which is called synthetic, depends upon the observed facts about something. In other words, to know the truth of the proposition is to accord it with the fact of the world. The other aspect of meaning related to synthetic proposition is reference. It deals with the relationship between words and the non-linguistic world of experience (Palmer, 1981, p.30). Reference thus needs an observation from the external world of language to know the world's fact. For example, All bachelors are miserable. The truth of the sentence is obtained from the observation of the condition of all bachelors. The truth, then gives additional information about the bachelors who in this case are miserable.

In this study, the propositions in the stanzas of Gambuh are analyzed in terms of its analytic and synthetic ones in which the truth value of the sentence is knowable by both knowing the meaning of the words and something about the world. For example, the sentence All men are less than nine feet tall may be true if it occurs universally, but in fact it may occur only in some parts of earth.

The Wedhatama perceives the philosophical element as an exclusive phenomenon engendered by Indonesian's nature, history and culture. As a result, observing the work scientifically is needed to acknowledge the linguistic frame -in terms of the propositions on how the mode of Javanese identity of prayer is perceived. It is therefore by exploring specifically the relationship between the sentences containing the analytic and synthetic propositions in Gambuh canto of the Wedhatama, the problem is how the Javanese identity of prayer is illustrated by the propositions in Gambuh canto of the Wedhatama. 


\section{Methods}

The Wedhatama script taken in this study is the officially edited version as it is cited in a book written by Stuart Robson in 1990 titled The Wedhatama: an English Translation. In doing so, Gambuh canto is taken as the sampling of this study since it has typical qualities in case that it is the conclusion of three other previous cantos of the Wedhatama. The data then are the lines in $25 \mathrm{stanzas}$ of Gambuh canto which consist of analytic and synthetic propositions as to figure out a Javanese concept within the poem. Meanwhile, in analysing the data, after finding the propositions in the stanzas, the researchers elaborate the esoteric knowledge of Javanese identity of prayer -borrowing Headley's (2004) term. In this case, in analyzing Kawi words used in the poem, the writers consult the book of Terjemahan by Yayasan Mangadeg (1975) since it provides the definition of the words completely. In addition, a book titled The Oxford History of Islam (Esposito, ed., 1999) is used to relate the proposition and the world of Islam.

\subsection{Javanese Identity of Prayer in Gambuh Canto}

The analytic and synthetic propositions in Gambuh were analyzed by using subject and predicate scheme. Analytic proposition is true because of the definition presented by the predicate and of the senses within the proposition. Meanwhile, synthetic proposition contains reference relations between the meaning of the word and something about the Islamic world.

In doing so, to distinguish between such propositions, the writers presented the proposition analysis of each stanza in case that the subject was bold and the predicate was underlined. It was done to make a clear analysis between the analytic and synthetic propositions. In this case, there were subjects of the proposition in some stanzas found in the preceding ones. For example, the subject in the proposition of stanza 5 was found as the same subject of stanza 4, the subject in the proposition of stanza 12 was found in stanza 11, the subject in the proposition of stanza 17 was found in stanza 16. Finally, the writers presented the following tables based on the theories of Palmer (1981) and Mundiri (2001) regarding the logical relation of analytic and synthetic propositions. Unfortunately, stanza 24 was not included since the writers could not find any proposition related to Javanese esoteric knowledge in it.

Table 1. Stanza 1

\begin{tabular}{|c|c|c|c|}
\hline \multirow{2}{*}{$\begin{array}{c}\text { Type of } \\
\text { Proposition }\end{array}$} & \multirow{2}{*}{ Key Words } & \multicolumn{2}{|c|}{ Logical Relation } \\
\hline & & Palmer & Mundiri \\
\hline Analytic & $\begin{array}{c}\text { Sembah catur raga cipta } \\
\text { jiwa rasa }\end{array}$ & Hyponymy & Compatibility \\
\hline Synthetic & $\begin{array}{c}\text { lamun katemu tandha } \\
\underline{\text { nugrahaning Manon }}\end{array}$ & Observed fact & Observed fact \\
\hline
\end{tabular}

The analytic and synthetic propositions are found in stanza 1. It is signified by discovering the hyponymy relationship between 'sembah catur' as the subject and 'raga, cipta, jiwa, rasa' as the predicate, which means that Islam is undergone in terms of theoretical and experiential knowledge. The conception of knowledge comprehends a reality that can be revealed by the human mind (cipta) and by the vision of spiritual intellect which includes the soul (jiwa) and the essence ( $r a s a$ ). Besides, the body ( $r a g a$ ) is used to make the required five prayers each day. In this case, the worships of raga, cipta, jiwa, and rasa, are the hyponyms of the four worships (sembah catur). Thus the truth of the proposition is compatible since 
there is an exact explanation between what is thought of as 'sembah catur' and the reality of Islamic life itself.

On the other hand, synthetic proposition obtains its truth depending on Islamic concept of the worships. In such a case, when an Islamic believer 'lamun tinemu' or does the four worships she may get 'nugrahaning Manon' as it is clearly stated in the Quran discourse Ali Imran verse 31 that Say: "If ye do love Allah, Follow me: Allah will love you and forgive you your sins: For Allah is Oft-Forgiving, Most Merciful."

Table 2. Stanza 2

\begin{tabular}{cccc}
\hline Type of & Key Words & Logical Relation \\
\cline { 3 - 4 } Proposition & Sembah raga, amagang & Mundiri \\
\hline Analytic & $\begin{array}{l}\text { laku, susuciné asarana } \\
\text { saking warih, limang waktu, }\end{array}$ & Definition & No contradiction \\
& $\frac{}{\text { wantu wataking wawaton }}$ & & \\
\hline
\end{tabular}

The writers found an analytic proposition in stanza 2. The analytic proposition is about the definition of the subject 'sembah raga' which means prayers. The prayers, one of five pillars of Islam, are performed five times (limang waktu) just before dawn, at noon, at mid-afternoon, just after sunset, and in the evening, from an hour after sunset to around midnight. To perform the prayer, the believer must first put herself in a state of purity by doing ablution using clean water (susuciné asarana saking warih). Additionally, the prayer becomes the contrast between the absolute independence of God and the dependency of human beings which is affirmed in the actions (amagang laku) of the prayer. Overall, there is no contradiction of 'sembah raga' and 'amagang laku' since the prayer requires physical objects related to the body, such as water for the ablution. What is known as 'amagang laku' is actually 'wantu wataking wawaton' which means the prayer is a rule established in the Hadith of Gabriel.

Table 3. Stanza 3

\begin{tabular}{|c|c|c|c|}
\hline \multirow{2}{*}{$\begin{array}{c}\text { Type of } \\
\text { Proposition }\end{array}$} & \multirow{2}{*}{ Key Words } & \multicolumn{2}{|c|}{ Logical Relation } \\
\hline & & Palmer & Mundiri \\
\hline Synthetic & $\begin{array}{c}\begin{array}{c}\text { Ing nguni-uni durung, } \\
\text { sinarawung wulang kang }\end{array} \\
\frac{\text { sinerung, }}{\text { lagi iki bangsa kas_ }} \\
\text { ngetokken anggit, } \\
\text { Mintokken kawignyanipun } \\
\text { saréngate élok-élok. }\end{array}$ & Observed fact & Observed fact \\
\hline
\end{tabular}

The writers only found the synthetic proposition in stanza 3 which was recognized by doing observation of the condition of teachings (sinarawung wulang) in the past decades (nguni-uni durung) that according to the author of the Wedhatama, in the present time the author lived, the teachings were shown (ngetokken) in strange ways (élok-élok). Those things become the additional information for 'sinarawung' since they are not necessary to be its part. 
Table 4. Stanza 4

\begin{tabular}{|c|c|c|c|}
\hline \multirow{2}{*}{$\begin{array}{c}\text { Type of } \\
\text { Proposition }\end{array}$} & \multirow{2}{*}{ Key Words } & \multicolumn{2}{|c|}{ Logical Relation } \\
\hline & & Palmer & Mundiri \\
\hline Analytic & $\begin{array}{l}\text { kaya santri Dul,kaya santri } \\
\frac{\text { brai kidul sauruté Pacitan }}{\text { pinggir pasisir }}\end{array}$ & Synonymy & Compatibility \\
\hline Synthetic & $\begin{array}{c}\text { ewon wong kang padha } \\
\text { gugu, anggeré padha } \\
\underline{\text { nyalemong }}\end{array}$ & Observed fact & Observed fact \\
\hline
\end{tabular}

The analytic and synthetic propositions were found in stanza 4. It is seen in the sameness relationship or known as synonymy. 'Santri Dul' is synonymous with 'santri brai' which are located in 'kidul sauruté Pacitan pinggir pasisir.' Both 'santri Dul' and 'santri brai' indicate the same religious pupils. They are a sectarian group of Muslims whose practices spread over parts of Java in the early part of the $19^{\text {th }}$ century. Moreover, they followed tenet named 'Guyeng Dul' and in practice they rode on 'kuda lumping' (horse made of plait work with which men danced themselves into a trance). The truth of the analytic proposition is also compatible shown by the propositions within the stanza and the reality that the 'santri' existed.

Meanwhile, the synthetic proposition is known from the observation of the people who followed what the 'santri' did (ewon wong kang padha gugu). Even though the 'santri' talked gibberish (anggeré padha nyalemong), the people who did not know about the tenet followed it. In this case, there was additional information about the tenet which could be compared to another case where many people might not follow the tenet performed by the 'santri.'

Table 5. Stanza 5

\begin{tabular}{cccc}
\hline Type of & & \multicolumn{2}{c}{ Logical Relation } \\
\cline { 3 - 4 } Proposition & Key Words & Palmer & Mundiri \\
\hline Synthetic & $\frac{\text { Kasusu arsa weruh, }}{\text { cahyaning Hyang kinira yèn }}$ & & \\
& $\frac{\text { karuh, ngarep-arep urub }}{\text { arsa dèn-kurebi; Tan weruh }}$ & Observed fact & Observed fact \\
& $\frac{\text { yèn urip iku akalé kaliru }}{\text { enggon }}$ & & \\
\hline
\end{tabular}

The truth of the synthetic proposition in stanza 5 is known by conducting an observation of the condition of the followers (ewon wong kang padha gugu) of the tenet performed by the 'santri.' This observation that might be done by the author adds new information to the followers. For example, they were in a hurry to see the light they thought of as God's light' (kasusu arsa weruh cahyaning Hyang kinira yèn karuh) and to obtain it (ngarep-arep urub arsa dèn-kurebi). 
Table 6. Stanza 6

\begin{tabular}{cccc}
\hline Type of & Key Words & \multicolumn{2}{c}{ Logical Relation } \\
\cline { 3 - 4 } Proposition & Palmer & Mundiri \\
\hline Synthetic & $\begin{array}{c}\text { bangsa sréngat tan winor } \\
\text { lan laku batin, dadi nora } \\
\text { duwé bingung, kang padha }\end{array}$ & Observed fact & Observed fact \\
& $\frac{\text { nembah Hyang Manon }}{2}$ & & \\
\hline
\end{tabular}

The synthetic proposition in stanza 6 is known by conducting an observation of the condition of the Islamic life. The author stated that time after time (jaman rumuhun) things were reformed continuously by the generations (tata titi tumrah tumaruntun). For example, in the past time the Shariah (bangsa sréngat) was not mixed with fiqh (laku batin). As a result, Islamic law which was reflected in both terms did not make the followers confused (bingung) in worshiping God (nembah Hyang Manon).

Table 7. Stanza 7

\begin{tabular}{cccc}
\hline $\begin{array}{c}\text { Type of } \\
\text { Proposition }\end{array}$ & Key Words & Palmer & Mundiri \\
\cline { 3 - 4 } Analytic & Saréngat, $\underline{\text { laku, ajeg, }}$ & Hyponymy & Compatibility \\
Synthetic & Pakolihé, $\underline{\text { nyenyeger badan }}$ & & \\
& $\underline{\text { mrih kaot }}$ & Observed fact & Observed fact \\
\hline
\end{tabular}

There are analytic and synthetic propositions found in stanza 7. The analytic proposition is acknowledged within hyponymy relationship of 'saréngat' and 'laku', (the Islamic law or 'Shariah', discipline or 'fiqh'). 'Shariah' is defined as the clear ruling on the fundamentals of Islam, such as prayers, fasting, pilgrimage to Mecca, etc. Meanwhile, 'fiqh' is defined as the knowledge of the practical rules of the Shariah, such as the essential of worship, the rules of inheritance, etc. In this case, 'laku' is the hyponym of 'saréngat.' Besides, both terms signify compatibility concerning the Islamic law described in the proposition. Moreover, the synthetic proposition is true because there is a necessity to observe the fact about the condition after using (pakolihé) the law (laku). As a result, there is additional information that the law may refresh the body (nyenyeger badan).

Table 8. Stanza 8

\begin{tabular}{cccc}
\hline Type of & & \multicolumn{2}{c}{ Logical Relation } \\
\hline Proposition & Key Words & Palmer & Mundiri \\
\cline { 3 - 4 } Synthetic & $\begin{array}{c}\text { Wong seger badanipun, } \\
\text { otot daging kulit balung } \\
\text { sungsum, tumrah ing rah } \\
\text { mamarah antenging ati, }\end{array}$ & Observed fact & Observed fact \\
& $\begin{array}{l}\text { antenging ati nunungku, } \\
\text { angruwat ruweding batos }\end{array}$ & & \\
\hline
\end{tabular}

The stanza contains synthetic proposition which is known by conducting an observation on the body of the believer and the inside parts such as 'otot', 'daging', 'kulit', 'balung', and 'sungsum.' Afterwards, the observation indicates whether the health body and its parts may cause peace of mind (antenging ati) and banish inner confusion (angruwat ruweding 
batos).

Table 9. Stanza 9

\begin{tabular}{cccc}
\hline Type of & Key Words & Logical Relation \\
\cline { 3 - 4 } Proposition & Parèhning asnafun, béda- & Mundiri \\
\hline Analytic & $\begin{array}{c}\text { béda panduk panduming } \\
\text { dumadi, sayektiné nora }\end{array}$ & & \\
& $\frac{\text { jumbuh tékad kang padha }}{\text { linakon }}$ & & Compatibility \\
\hline
\end{tabular}

It is analytically true since there is a synonymy relationship between 'sarèhning asnafun', 'béda panduk', and 'nora jumbuh tékad.' The analytic proposition showes that the different characteristics (sarèhning asnafun) of human can impact on the different direction, lot of life, and paths (panduk, dumadi, tékad).

Table 10. Stanza 10

\begin{tabular}{cccc}
\hline Type of & Key Words & Logical Relation \\
\cline { 3 - 4 } Proposition & Sing sapa temen tinemu, & Mundiri \\
\hline Synthetic & $\begin{array}{c}\text { nugraha geming kaprabon } \\
\text { nyy }\end{array}$ & Observed fact & Observed fact \\
\hline
\end{tabular}

The writers found synthetic proposition in stanza 10 in which to know its truth the human should assign to the real world by conducting an observation on the life of the believer who performs the worship sincerely (temen tinemu). The observation then is necessary to know whether the believer obtaines worth from God (nugraha geming kaprabon).

Table 11. Stanza 11

\begin{tabular}{|c|c|c|c|}
\hline \multirow{2}{*}{$\begin{array}{c}\text { Type of } \\
\text { Proposition }\end{array}$} & \multirow{2}{*}{ Key Words } & \multicolumn{2}{|c|}{ Logical Relation } \\
\hline & & Palmer & Mundiri \\
\hline Synthetic & $\begin{array}{c}\text { sembah kalbu, yen luminta } \\
\text { uga dadi laku, laku agung } \\
\text { kang kagungan narapati, } \\
\text { patitis teteping kawruh } \\
\frac{\text { meruhi marang kang }}{\text { momong }}\end{array}$ & Observed fact & Observed fact \\
\hline
\end{tabular}

There is a synthetic proposition found in stanza 11. It is shown by observing facts of the worship of the thought (sembah kalbu) and 'laku agung kang kagungan narapati.' In Islamic life, the certainty refers to the knowledge that results from the human capacity for logical reasoning of her thought and the appraisal of God's presence in the world. In this case, there is a compatibility between the logical reasoning which comes from thought and the knowledge which is learnt by human using her thought. Moreover, the synthetic proposition is true based on the observation of the believers who can acknowledge God (meruhi marang kang momong), thus it may result additional information to the believers. In fact, not all believers did acknowledge God because it iss hard to do, unless they have enough knowledge of religious teaching. 
Table 12. Stanza 12

\begin{tabular}{lllc}
\hline \multirow{2}{*}{$\begin{array}{c}\text { Type of } \\
\text { Proposition }\end{array}$} & \multicolumn{1}{c}{ Key Words } & \multicolumn{2}{c}{ Logical Relation } \\
\cline { 2 - 3 } Synthetic & $\frac{\text { Suciné tanpa banyu, }}{\text { amung nyunyuda ardaning }}$ & Observed fact & Observed fact \\
& $\underline{\text { kalbu, }}$ & \\
\hline
\end{tabular}

The writers find synthetic proposition in stanza 12. The proposition becomes the additional information of 'sembah kalbu' by conducting an observation. The additional information will be the ablution is without water (suciné tanpa banyu) since the believers may lessen the heart (nyunyuda ardaning kalbu).

Table 13. Stanza 13

\begin{tabular}{cccc}
\hline $\begin{array}{c}\text { Type of } \\
\text { Proposition }\end{array}$ & \multicolumn{1}{c}{ Key Words } & \multicolumn{2}{c}{ Logical Relation } \\
\cline { 3 - 4 } & $\begin{array}{c}\text { Mring jatining pandulu } \\
\text { Panduking don dadalan }\end{array}$ & & Mundiri \\
\hline Synthetic & $\frac{\text { satuhu, lamun lugu }}{\text { legutaning rèh maligi }}$ & Observed fact & Observed fact \\
& Lagèhané tumalawung & & \\
& Wenganing alam kinaot & & \\
\hline
\end{tabular}

The writers found synthetic proposition in stanza 12. The proposition becomes the additional information by conducting an observation of the worship of the thought in which through the real thought (jatining pandulu) the effort to reach higher spiritual life (panduking) is fulfilled.

Table 14. Stanza 14

\begin{tabular}{cccc}
\hline $\begin{array}{c}\text { Type of } \\
\text { Proposition }\end{array}$ & Key Words & Polmer & Mundiri \\
\cline { 3 - 4 } & $\begin{array}{c}\text { Sarat sarèh saniskarèng } \\
\text { Saku, kalakoné saka eneng, }\end{array}$ & & \\
Synthetic & $\frac{\text { Oning, éling, ilanging rasa }}{\text { ention }}$ & Observed fact & Observed fact \\
& $\frac{\text { tumlawung, kono adiling }}{\text { Hyang Manon }}$ & & \\
\hline
\end{tabular}

The proposition in stanza 14 is synthetically true since there is additional information to the way to reach higher spiritual life (sarat) obtained from an observation. The information is the way to reach the life (kalakoné saka eneng, ening, éling) and after that the way can make desire disappear (ilanging rasa tumlawung). As the result, the believer can see God's righteousness (kono adiling Hyang Manon).

Table 15. Stanza 15

\begin{tabular}{cccc}
\hline Type of & Key Words & \multicolumn{2}{c}{ Logical Relation } \\
\cline { 3 - 4 } Proposition & Gagaréngunggar kayun, & Mundiri \\
\hline Synthetic & $\frac{\text { ngayun-ayun mring ayuning }}{\text { kayun, bangsa anggit yèn }}$ & Observed fact & Observed fact \\
& $\frac{}{\text { ginigit nora dadi }}$ & & \\
\hline
\end{tabular}


On the other hand, synthetic proposition in stanza 15 is true based on the observation of the condition of the believer who is failed (gagaré) in performing the worship of the thought because she wants to exquisite her desire (gagare ngunggar kayun) and hopes its fulfilment (ngayun-ayun mring ayuning kayun). In this case, her desire is nothing compared to what may be obtained from God in performing the worship sincerely (bangsa anggit yèn ginigit nora dadi).

Table 16. Stanza 16

\begin{tabular}{|c|c|c|c|}
\hline \multirow{2}{*}{$\begin{array}{c}\text { Type of } \\
\text { Proposition }\end{array}$} & \multirow{2}{*}{ Key Words } & \multicolumn{2}{|c|}{ Logical Relation } \\
\hline & & Palmer & Mundiri \\
\hline Analytic & $\begin{array}{c}\text { sembah katri, sembahing } \\
\text { jiwa }\end{array}$ & Hyponymy & Compatibility \\
\hline
\end{tabular}

The analytic proposition in stanza 16 is acknowledged within hyponymy relationship of the types of worship. The third type of worship (sembah katri) is the worship of the soul (sembahing jiwa). Additionally, it is compatible with Islamic law in which performing worship also underlays the occurrence of the soul alertness.

Table 17. Stanza 17

\begin{tabular}{cccc}
\hline $\begin{array}{c}\text { Type of } \\
\text { Proposition }\end{array}$ & Key Words & Palmer & Mundiri \\
\cline { 2 - 4 } Analytic & $\frac{\text { kalakuwan kang tumrap }}{\text { bangsaning batin }}$ & Definition & Compatibility \\
\hline Synthetic & $\begin{array}{c}\text { suciné lan awas émut, } \\
\text { mring alaming lama amot }\end{array}$ & Observed fact & Observed fact \\
\hline
\end{tabular}

The writers found analytic and synthetic propositions in stanza 17. The analytic proposition, whose subject is found in stanza 16 (sembah jiwa), is known from the definition relationship and the compatibility within proposition. 'Sembah jiwa' is defined into 'kalakuwan kang tumrap bangsaning batin' which means that it is related to the heart. In accordance with Islamic life, the knowledge which is revealed in this worship is called 'eye of certainty.' It refers to the knowledge acquired by the spiritual intelligence, which Islam locates metaphorically in the heart. In fact, the truth of synthetic proposition is obtained by observing the Islamic world of the worship. Then the additional information will result from knowing that the ablution needed in the worship consists of insight and mindfulness of the life (sucinélan awas émut,mring alaming lama amot).

Table 18. Stanza 18

\begin{tabular}{|c|c|c|c|}
\hline \multirow{2}{*}{$\begin{array}{c}\text { Type of } \\
\text { Proposition }\end{array}$} & \multirow{2}{*}{ Key Words } & \multicolumn{2}{|c|}{ Logical Relation } \\
\hline & & Palmer & Mundiri \\
\hline Synthetic & $\begin{array}{l}\text { Ruktiné ngangkah ngukut, } \\
\text { ngiket ngruket triloka } \\
\text { kakukut, jagad agung } \\
\text { ginulung lan jagad alit }\end{array}$ & Observed fact & Observed fact \\
\hline
\end{tabular}


The synthetic proposition in stanza 18 is true based on the observation of the preparation (ruktiné) of the higher spiritual life in the importance of the worship of the soul. There are several concepts of the worship. 'Ngangkah' means aiming, 'ngukut' means summarising, 'ngiket' means binding up, and 'ngruket' means tying fast. In addition, there are two other concepts, namely 'jagad agung' or the universe and 'jagad alit' or the earth. All concepts should be observed in order to know the truth of the proposition.

Table 19. Stanza 19

\begin{tabular}{cccc}
\hline $\begin{array}{c}\text { Type of } \\
\text { Proposition }\end{array}$ & Key Words & Palmer & Mundiri \\
\cline { 2 - 3 } Synthetic & $\begin{array}{c}\text { Kelemé mawi limut, } \\
\text { kalamatan jroning alam }\end{array}$ & Observed fact & Observed fact \\
\hline
\end{tabular}

The stanza is true synthetically since it depends on the fact about the world of the worship of the soul indicated by the condition of the believer. The believer who wants to become the part of the worship may forget about her secular life (kelemé mawi limut) and get guidance in the sweeping universe (kalamatan jroning alam kanyut).

Table 20. Stanza 20

\begin{tabular}{|c|c|c|c|}
\hline \multirow{2}{*}{$\begin{array}{c}\text { Type of } \\
\text { Proposition }\end{array}$} & \multirow{2}{*}{ Key Words } & \multicolumn{2}{|c|}{ Logical Relation } \\
\hline & & Palmer & Mundiri \\
\hline Synthetic & $\begin{array}{c}\text { Pamèté saka luyut, } \\
\frac{\text { sarwa sarèh saliring }}{\text { panganyut, }} \\
\frac{\text { lamun yitna kayitnan kang }}{\text { miyatani }}\end{array}$ & Observed fact & Observed fact \\
\hline
\end{tabular}

The synthetic proposition in stanza 20 is true based on the observation of Islamic world that there are ways to acquire the knowledge of the divinity (pamèté): saka luyut, sarwa sarèh saliring panganyut, lamun yitna kayitnan kang miyatani. The ways are the additional information for the worship of the soul.

Table 21. Stanza 21

\begin{tabular}{cccc}
\hline $\begin{array}{c}\text { Type of } \\
\text { Proposition }\end{array}$ & Key Words & Palmer & Mundiri \\
\cline { 3 - 4 } Analytic & $\begin{array}{c}\text { sajatiné urub, urub } \\
\text { pangarep uriping budi }\end{array}$ & Definition & Compatibility \\
\hline
\end{tabular}

The analytic proposition in stanza 21 is based on the definition relationship between the divine light (sajatiné urub) which leads the believer toward remembrance of the Creator (urub pangarep uriping budi). As a result, there is compatibility between the proposition and the reality of Islam that before obtaining the light, the believer must first be opened to Islam. 
Table 22. Stanza 22

\begin{tabular}{cccc}
\hline $\begin{array}{c}\text { Type of } \\
\text { Proposition }\end{array}$ & Key Words & Lolmer & Mundiri \\
\cline { 2 - 4 } & Yèku wenganing kalbu, \\
Synthetic & $\frac{\text { kabuka ta kang wengku- }}{\text { winengku }}$ & Observed fact & Observed fact \\
\hline
\end{tabular}

The synthetic proposition in stanza 22 is true based on the observation of the opening of the soul (yèku wenganing kalbu). In this case, 'what contains' and 'is contained' are open (kabuka ta kang wengku-winengku).

Table 23. Stanza 23

\begin{tabular}{cccc}
\hline Type of & Key Words & \multicolumn{2}{c}{ Logical Relation } \\
\cline { 3 - 4 } Proposition & Palmer & Mundiri \\
\hline Analytic & $\begin{array}{c}\text { sembah ingkang kaping } \\
\text { catur, sembah rasa } \\
\text { karasa wosing dumadi, }\end{array}$ & Hyponymy & Compatibility \\
Synthetic & $\begin{array}{c}\text { dadiné wus tanpa tuduh, } \\
\text { mung kalawan kasing batos }\end{array}$ & Observed fact & Observed fact \\
\hline
\end{tabular}

The writers found analytic and synthetic propositions in stanza 23. The analytic proposition shows a hyponymy relationship of the worship number four (sembah ingkang kaping catur), namely the worship of the essence (sembah rasa). Regarding Islam, through which the compatibility can be determined, the knowledge contained in the worship of the essence is the highest level. It is called 'truth of certainty' which refers to the state of consciousness in which the believer knows the real through direct participation in it, without resorting to logical proofs. In addition, synthetic proposition in stanza 23 is true based on the observation of the performance of the worship of the essence. As the result, there is additional information of the worship: karasa wosing dumadi, dadiné wus tanpa tuduh, mung kalawan kasing batos.

Table 24. Stanza 25

\begin{tabular}{|c|c|c|c|}
\hline \multirow{2}{*}{$\begin{array}{c}\text { Type of } \\
\text { Proposition }\end{array}$} & \multirow{2}{*}{ Key Words } & \multicolumn{2}{|c|}{ Logical Relation } \\
\hline & & Palmer & Mundiri \\
\hline Synthetic & $\begin{array}{l}\text { Meloké ujar iku, } \\
\text { yèn wus ilang sumelanging } \\
\text { kalbu, amung kandel- } \\
\text { kumandel marang ing takdir }\end{array}$ & Observed fact & Observed fact \\
\hline
\end{tabular}

The synthetic proposition in stanza 25 depends on the observation of the believer whether she will understand the worship and perform it sincerely. According to Islam, the true Muslim who submits to God cannot delude herself by claiming that she is the author of her destiny. In this case, she can obtain the understanding of the guide (meloké ujar iku) when she knows that her fate is routinely influenced by factors beyond her control (yèn wus ilang sumelanging kalbu) and that she should believe in the fore-knowledge or qada and individual's fate or qadar (amung kandel-kumandel marang ing takdir). 


\section{Discussion}

In this study, after knowing how the words, in terms of subject concept and predicate concept, relate to each other, it is necessary to have knowledge of the world beyond the words to find out a concept within Gambuh canto.

The Wedhatama is considered a classic didactic essay in poetry which provides a window on the progressive acculturation of Islam and the persistence of other kinds of invocations. It also illustrates how typically Javanese notions of self have persisted in the practice of prayer. As a means to attain union with the Absolute, the prolongation of the five daily prayers is common to Muslim practices worldwide. However, the prolongation described by the author is something distinctly Javanese. The worship is not designated particularly as salat, but by a general label that is sembah as stanza 1 of Gambuh claims:

Now I shall teach the four kinds of worship/ so that you may acquire them/ firstly that of the body, then thought, the soul, and the essence, my boy/ The acquisition of these is a sign of favour from the All-Seeing.

As seen in the stanza, the poet is expressing the four kinds of worship (sembah) which are levels of self, hierarchically arranged. The first kind of worship, the bodily, designates the five daily prayers at the local prayer house or mosque. In such a case, the reflections on the deepening levels of worship are found in many forms in Islam, but not employing such Javanese expressions. It can be seen in the people's condition stated in stanza 5, for instance, in which the Wedhatama's author must have observed. The author must have seen the condition so that he could say that the people 'ngarep-arep urub arsa dèn-kurebi' or expect the coming of the light they will cover. Moreover, its truth depends on what the universe is like. According to the author, the easy way to get this light is not correct as stated in 'akale kaliru enggon'. The synthetic truth of the statement of 'tan weruh yen urip iku, akale kaliru enggon', then, is obtained from the fact in the world that what people think as the easy way to get in touch with God is wrong due to they rarely want to sacrifice their matters in worshiping.

The meaning of this stanza is obtained from the lines. It is stated in lines 1-2 'Kasusu arsa weruh, cahyaning Hyang kinira yen karuh'. In fact, they are lack of the knowledge of mercy of God. People can obtain it by being faithful to God. They also 'ngarep-arep urub arsa den-kurebi' or look for glow of the light. According to the author, the opinion is incorrect as stated in the lines 'tan weruh yen urip iku akale kaliru enggon'.

Another stanza which indicates synthetic proposition is stanza 15. It tells about the failure of the opening the heart. These matters are known based on the author's sensory on his opening heart experience, and thus the truth of 'ngunggar kayun', 'ayuning kayun', and 'bangsa anggit' is in accordance with the result of the author's experience.

Knowing that stanza 15 contains synthetic propositions, the meaning of the stanza is understandably recognized. It is begun by the word 'gagare' meaning human will be failed in improving his spiritual life because he 'ngunggar kayun' (gives a loose to anything he wants), such as 'ngayun-ayun' (hope) of 'ayuning kayun' or acceptance from other people for an achievement. In the third line the achievement is considered as 'bangsa anggit' (fantasy) since it is actually temporary desire which may be just a fantasy. This fantasy when 'ginigit' (tested) may make the worship 'nora dadi' (continually failed).

Additionally, stanza 25 indicates synthetic propositions as well. As stated in line 1 'meloke' (clear understanding) comes when 'sumelanging kalbu' (the inner anxiety that covers heart) has 'ilang' (vanished). Then the human needs to 'kandel-kumandel' (believe 
earnestly) in 'takdir' (destiny). Its truth depends on the personal acceptance because each person has different ' $k a l b u$.' Stanza 25 presents meaning about the reminding that 'meloke' or the clear understanding which are 'ujar' (told) comes when human can 'ilang' or vanish 'sumelanging' (inner anxiety) that covers 'kalbu' (heart). To vanish the anxiety is by 'kandel-kumandel' (believe earnestly) in 'takdir' (fate).

After all, through a meaningful analysis of Gambuh canto, it is argued that Mangkunegara IV offers rules for centering the synthetic propositions which are subjective and emerged within culturally constituted ideational matrices. These ideational matrices rest upon his experience and wisdom on Islam and are given out in the same manner wheresoever the ways to higher knowledge are indicated. In this perspective, Headley (2004) argues that a remarkable feature of Islam is how consistent over a wide area is the use of Arabic terms for different kinds of prayer and invocation. In Islam, the terminological distinctions of divine invocation are much more tightly codified. When Javanese pray at the mosque, nearly nothing they do differs in its exterior from what is done in mosques throughout the Middle East. Reflections on the deepening levels of sembah are found in many forms in Islam, but not employing such Javanese expressions. In Gambuh canto stanza 8 of the Wedhatama, the poet claims that worship by the body and the discipline of Islamic law that regulates it, is refreshing.

\section{Conclusion}

This study is an effort to bridge linguistics and logic and thus to encourage closer cooperation between logicians and linguists in their common study of the structure of language. If culture is a resource for a society to negotiate the socio-material environment, then there is a remark in Gambuh canto of the Wedhatama that both the cause of and solution to the social problems which demanded such an attention as given in this canto could be found in the society's culture. Therefore, it is seen that Mangkunegara IV set out to contribute to the negotiation of the culture of his day and that his attempt may be crucially assessed through an investigation of the textual resources. In this way, Mangkunegara IV was able to negotiate complex meanings within this interaction and express Javanese ritual practice in his own term through this textual design as a simple and sacred truth.

\section{References}

Boogert, Jochem van den. (2015). Rethinking Javanese Islam: Towards new descriptions of Javanese traditions. Retrieved June 20, 2016] from https://openaccess.leidenuniv. $\mathrm{nl} /$ bitstream/handle/1887/36400/08.pdf? sequence $=7$

Esposito, John L. (ed.). (1999). The Oxford History of Islam. New York: Oxford University Press.

Headley, Stephen C. (2004). Durga's Mosque: Cosmology, Conversion and Community in Central Javanese Islam. Singapore: Institute of Southeast Asian Studies.

Mcgrath, Matthew. (2005). Propositions. Retrieved February 2, 2016, from http://plato. stanford.edu/entries/propositions/

Mundiri. (2001). Logika. Jakarta: PT. Raja Grafindo Persada.

Palmer, F.R. (1981). Semantics (2 ${ }^{\text {nd }}$ ed.). Cambridge: Cambridge University Press.

Robson, Stuart. (1990). The Wedhatama: An English Translation. Leiden: KITLV Press. 
Sulistyo, Edy T. (2015). The implicature of tembang Gambuh in Serat Wedhatama and its significance for the society. Humaniora., 27(1) pp 96-106, Retrieved February 12, 2016 from https://doaj.org/article/2c5ededeee9d4828bf0f0513a03a745f_

Widodo, Sahid Teguh. (2015). The concept of a social organism: the response of Javanese society to modernism in the Serat Wedhatama by Kangjeng Gusti Pangeran Adipati

Arya (K.G.P.A.A.) Mangkunegara IV. Pertanika: Journal of Social Sciences and Humanities, 24(1), pp 519-526, Retrieved May 12, 2016, from http://www.pertanika. upm.edu.my/Pertanika\%20PAPERS/JSSH\%20Vol.\%2024\%20\%281\%29\%20 Mar.\%202016/31\%20JSSH-1324-2015.pdf

Woodward, Mark. (2011). Java, Indonesia, and Islam. Netherlands: Springer. 